\title{
Comparative analysis of synthetic natural gas versus hydrogen production from bagasse
}

DOI:

10.1002/ceat.201600424

\section{Document Version}

Accepted author manuscript

Link to publication record in Manchester Research Explorer

\section{Citation for published version (APA):}

Michailos, S., Parker, D., \& Webb, C. (2017). Comparative analysis of synthetic natural gas versus hydrogen production from bagasse: A multi-criteria approach. Chemical Engineering and Technology, 40(3), 546-554. https://doi.org/10.1002/ceat.201600424

\section{Published in:}

Chemical Engineering and Technology

\section{Citing this paper}

Please note that where the full-text provided on Manchester Research Explorer is the Author Accepted Manuscript or Proof version this may differ from the final Published version. If citing, it is advised that you check and use the publisher's definitive version.

\section{General rights}

Copyright and moral rights for the publications made accessible in the Research Explorer are retained by the authors and/or other copyright owners and it is a condition of accessing publications that users recognise and abide by the legal requirements associated with these rights.

\section{Takedown policy}

If you believe that this document breaches copyright please refer to the University of Manchester's Takedown Procedures [http://man.ac.uk/04Y6Bo] or contact uml.scholarlycommunications@manchester.ac.uk providing relevant details, so we can investigate your claim.

\section{OPEN ACCESS}




\title{
Comparative analysis of synthetic natural gas versus hydrogen production from bagasse: A multi-criteria approach
}

\author{
Stavros Michailos ${ }^{1}$, David Parker ${ }^{2}$, Colin Webb ${ }^{1, *}$ \\ ${ }^{1}$ School of Chemical Engineering and Analytical Science, The University of Manchester, Oxford Road, \\ Manchester, M13 9PL, UK \\ ${ }^{2}$ School of Biosciences, University of Exeter, Stocker Road, Exeter, EX4 4QD, UK \\ *Correspondence: Colin Webb (E-mail: colin.webb@manchester.ac.uk), School of Chemical Engineering and \\ Analytical Science, The University of Manchester, Oxford Road, Manchester, M13 9PL, UK \\ Keywords: Bagasse utilisation, Multicriteria analysis, Process simulation, Synthetic gaseous fuels
}

\section{Abstract}

\begin{abstract}
The present study makes a rigorous and comparative evaluation of two biomass to gases (BtG) conversion routes and according to this outcome, suggests which of the options evaluated is most desirable. These options, the hydrogen and synthetic natural gas (SNG) production, were designed in Aspen plus process simulation software. Sugar cane bagasse, the waste solid residue of the sugar cane milling process, was considered as feedstock at a flowrate of $100 \mathrm{t} \mathrm{h}^{-1}$. Mass and energy balance data were extracted from the simulations, and consequently thermodynamic (exergy analysis), economic (financial and uncertainty analysis) and environmental ( $\mathrm{CO}_{2}$ emissions) evaluations were carried out. Exergy and environmental analysis favour the SNG production while the hydrogen route provides higher profits. The study concludes with multicriteria decision analysis (MCDA) where each process is attributed a score based on the investigated criteria. It was concluded that overall the most efficient option was the SNG production.
\end{abstract}

\section{Introduction}

The fluctuations in oil prices, as well as the increases in greenhouse gas emissions have motivated researchers to explore alternative sources of energy that have the potential to provide sustainability. As a result, the biorefinery platform continues to advance and various conversion routes attract increased attention as new technologies are developed. An example of the more recent developments involves the utilization of industrial waste material to value added products manufacture [1]. However, no robust technology for maximizing the value of wastes and residues from such biorefineries has yet been established. Sugarcane is presently the most cost effective feedstock for biofuel (ethanol) production and could be even more cost effective if the waste bagasse, a lignocellulosic material, could also be converted to biofuels. [2]. The processing of such wastes, including bagasse, can produce fuels, the so-called "second generation biofuels" that, can potentially overcome the issues facing "first generation biofuels" (e.g. food and land competition) [3]. A large number of technologies exist for conversion of biomass to a wide range of solid, liquid and gaseous fuels including gasification, pyrolysis and fermentation. Biomass gasification is a

Received: August 03, 2016; revised: September 28, 2016; accepted: December 12, 2016

This article has been accepted for publication and undergone full peer review but has not been through the copyediting, typesetting, pagination and proofreading process, which may lead to differences between this version and the final Version of Record (VOR). This work is currently citable by using the Digital Object Identifier (DOI) given below. The final VoR will be published online in Early View as soon as possible and may be different to this Accepted Article as a result of editing. Readers should obtain the final VoR from the journal website shown below when it is published to ensure accuracy of information. The authors are responsible for the content of this Accepted Article.

To be cited as: Chem. Eng. Technol. 10.1002/ceat.201600424

Link to final VoR: https://doi.org/10.1002/ceat.201600424

This article is protected by copyright. All rights reserved. 
promising technology for the production of synthetic fuels such as gasoline, methanol, diesel, hydrogen and SNG. Sasol and Mobil [4] have already successfully commercialized production of these fuels from coal via gasification. Compared to liquid fuels the production of bio-gases is more efficient due to high product selectivity (low by-products generation) and relative simpler upgrading units [4]. As a result, the sustainable production of hydrogen and SNG is of high interest.

The biomass conversion routes to methane can be categorized into biochemical (biomethane) and thermochemical (SNG). During the former, wet biomass including crops, sewage sludge and manure can be converted to biogas by anaerobic digestion and then upgraded to biomethane. However, the high concentrations of $\mathrm{CO}_{2}$ in the biogas result in low overall energy efficiencies of 20-40\% [5]. On the other hand, the thermochemical route can handle a wider range of feedstocks (including lignocellulosic) and achieve higher methane yields [6]. It has been, also, reported in previous studies that replacing fossil technologies with SNG systems provides several environmental benefits with respect to global warming [7]. In principle, the thermochemical conversion of biomass to SNG is a two stage process. The first step is the production of a gas mixture, known as syngas (mainly consisting of hydrogen and carbon monoxide), through gasification and the second is the methanation of the syngas. The SNG can utilise the prevailing natural gas distribution network and can be used in CHP applications by a wide range of domestic, commercial and industrial users, wherever natural gas is currently used, without additional investment. In addition, it can fuel gas vehicles and so contribute to the decarbonisation of road transport. In the past, several studies investigated the feasibility of biomass to $S N G$ route $[8,9,10]$. As a result, techno-economic analyses were conducted with the aim of estimating the economic and energetic potential of the process. The calculated exergy efficiencies were in the range of $60 \%-70 \%$ while the production cost of SNG was from 15.6 to $27 \$ \mathrm{GJ}^{-1}$ depending on the plant capacity.

Hydrogen is an energy carrier and can be produced from a wide variety of primary energy sources and different production technologies. Nowadays, hydrogen is usually generated from fossil sources including petroleum, natural gas and coal. In short, fossil fuel-based processes (mainly reforming) account for $95 \%$ of global hydrogen production [11]. Hydrogen production from nonrenewable sources comes with $\mathrm{CO}_{2}$ emissions which is the chief contributor to the so-called "greenhouse effect" [12]. The production of hydrogen, using as starting material a renewable source, is ideal for progressively substituting fossil fuels [13]. In view of this, hydrogen can be also produced from biomass via gasification or pyrolysis. During gasification the producer gas is shifted to hydrogen while during pyrolysis bio-oil is catalytically reformed to hydrogen. Sarkar et al. $[14,15]$ have tested these technologies and concluded that the gasification route provides significantly lower production costs, i.e. $12.4 \$ \mathrm{GJ}^{-1}$ compared to $28.1 \$ \mathrm{GJ}^{-1}$. Furthermore, the exergetic performance of the process has been investigated, in the past, and the reported values of the exergy efficiency vary from $50 \%$ to $60 \%$ $[15,16]$. Nevertheless, hydrogen manufacture faces significant challenges. The yield of hydrogen from biomass is relatively low since the hydrogen content in biomass is low to begin with (approximately $6 \%$ versus $25 \%$ for methane) [17]. Additionally, there is not yet an effective infrastructure for distributing hydrogen. A promising method for hydrogen production from biomass is via supercritical water gasification. It has received much attention as it is safe, non-toxic, readily available, inexpensive (biomass drying is not needed) and environmentally benign [18]. Nevertheless, severe conditions (high temperature and pressure) have to be applied to meet the minimum reaction condition. Hence, the high costs (both capital and operating) are the biggest obstacle to the establishment of this technology [19]. Recent advances in hydrogen production from biomass gasification incorporate the utilization of membrane shift reactors, gasification membrane reactors or a combination of both [20]. This was, it is suggested that hydrogen yields could be enhanced and downstream costs could be reduced [21]. Nonetheless, these technologies are still being tested and are yet to be established on a large scale [20]. 
So far, to the best of our knowledge, no comparative assessment between the basic BtG processes was attempted. Thus, the present study focuses on integrating exhaustive process simulations, thorough exergetic, economic and environmental calculations to evaluate and compare the sustainability of the investigated processes, and eventually suggest the best alternative. This methodology provides a robust mechanism and can be used as a reliable decision making tool.

\section{Process simulation}

The inlet mass flow rate for both cases was set equal to $100 \mathrm{t} \mathrm{h}^{-1}$. User defined non-conventional solids were determined to symbolize bagasse and ash. Aimed at those modules two Aspen models were allocated: one for the density (DCOALIGT) and the second one enthalpy (HCOALGEN) that necessitates awareness of proximate analysis and ultimate analysis of the bagasse (see Table 1 [22]). The physical properties of the conventional components have been estimated by using the RedlichKwong-Soave cubic equation of state with Boston-Mathias alpha function (RKS-BM). This method is suitable for gas-processing, refinery and petrochemical applications such as gas plants, crude towers and ethylene plants [23]. For each pathway a model was developed in Aspen plus which performs the necessary material and energy balances. Subsequently, the extraction of useful information is possible in order to perform the assessment of each process. Both processes consist of some certain steps, namely, 1) bagasse pre-treatment (crushing and drying), 2) gasifier island, 3) syngas quenching and cleaning, 4) product synthesis and 5) heat and power generation system. An Aspen plus crusher block has been employed to simulate a gyratory crusher which chops bagasse to a final particle size of $2 \mathrm{~mm}$ [24]. Afterwards bagasse enters a dryer in order to reduce its moisture content to $10 \%$. The high initial moisture content of bagasse makes it necessary to employ a dryer so as to reduce subsequent heat losses in the gasifier unit. The fractional conversion of bagasse to water has been estimated by using a FORTRAN statement. A RSTOICH reactor was used to model the drying of bagasse. Even if, bagasse drying is not generally considered a chemical reaction, the RSTOICH module is capable of converting a portion of the bagasse to form water. Eq. (1) presents the chemical reaction for bagasse drying:

Bagasse (wet) $\rightarrow 0.0555 \mathrm{H}_{2} \mathrm{O}$

Aspen Plus treats all nonconventional components as if they have a molecular weight of 1.0. The reaction indicates that 1 mole (or $1 \mathrm{~kg}$ ) of bagasse reacts to form 0.0555 mole (or $1 \mathrm{~kg}$ ) of water. Then, a calculator block was used (includes FORTRAN statements) to specify the moisture content of the dried bagasse $(10 \%)$ and calculates the corresponding conversion of bagasse to water. More details about this technique can be found online in a report published by AspenTech regarding solids processing [25].The energy required for the drying process is provided by heat produced within the processes. Then bagasse enters the gasification unit. A steam fluidised bed gasifier was considered operating at $1100 \mathrm{~K}$ and $0.1 \mathrm{MPa}$. The RGIBBS reactor module was employed to simulate the gasifier which assumes an overall equilibrium and neglects the hydrodynamic and kinetic features of the reactor. This approach has been used before in several studies $[26,27]$ and it is suitable for feasibility studies but not for reactor design [28]. Tar formation was taken into consideration and was simulated as toluene. Toluene was selected as a model tar compound since it represents a chief stable aromatic product in the tars formed in high temperature $(>1000 \mathrm{~K})$ biomass gasification processes $[29,30]$. The tar yield was assumed to obey the empirical relation proposed by Corella et al. [31] as follows:

Tar $=35.98 \exp (-0.0029 \mathrm{~T})$

Where $T$ is the gasification temperature. In addition, as previously reported [32], most of nitrogen and sulfur contaminants in syngas occur as ammonia and hydrogen sulfide respectively and thereby, in this study, it was, also, assumed that the bagasse sulphur content is converted to $\mathrm{H}_{2} \mathrm{~S}$ and nitrogen to $\mathrm{NH}_{3}$. Afterwards two cyclones have been used, the first one separates the unreacted char from the 
producer gas and recycles it to the gasifier and the second distinguishes the ash from the gas mixture. The next step is to purify the producer gas, thus an RSTOICH reactor has been employed to simulate a catalytic reformer reactor mainly in order to remove tar and ammonia. The catalyst used in the tar reformer differs according to the objectives of each process, therefore for the SNG the catalyst used promotes mainly tar reforming since methane is the desired product (IImenite based catalyst [33]). On the other hand for $\mathrm{H}_{2}$ production it is desired that all of the hydrocarbons derived from the gasifier are reformed in a single reactor (commercial Nickel based catalysts [34]). The tar reformer operates at temperature of $1073 \mathrm{~K}$ and pressure of $1.7 \mathrm{MPa}$. Subsequently the acid gases $\mathrm{H}_{2} \mathrm{~S}$ and $\mathrm{CO}_{2}$ are removed by using a solution of monoethanolamine (MEA) in an absorber [35]. The entrainer is recovered in a stripper and recycled to the absorber. Figure 1 provides a simplified process schematic for the two alternatives.

(Table 1 here)

\section{$2.1 \mathrm{H}_{2}$ production}

After the abovementioned steps, $\mathrm{CO}$ has to be converted to $\mathrm{H}_{2}$, thus two shift reactors are introduced coupled with an intercooling stage. Initially syngas is cooled down to $633 \mathrm{~K}$ so as to meet the operating conditions of the first high temperature shift reactor (HTS) and subsequently another cooler is employed in order to lower the temperature of the HTS product stream to $473 \mathrm{~K}$ before entering the low temperature shift reactor (LTS) [16]. Steam is supplied to reformers from the CHP unit. Two REQUIIL reactors were employed to model the reactors where the water gas shift reaction takes place. The gas stream exiting the reformers comprises $80 \mathrm{~mol} \% \mathrm{H}_{2}$ which meets the minimum requirement (70 $\mathrm{mol} \%$ ) for an efficient and economically feasible purification procedure [36]. Hydrogen is purified in a pressure swing adsorption unit (PSA) where the purity attained is $99.9 \%$ while the achieved recovery was set equal to $90 \%$. Before the PSA unit water has to be removed from the gas stream in order to avoid damage to the adsorbent (active carbon and zeolites mixture). Hence the gas stream is cooled down to $313 \mathrm{~K}$, then condensed water is removed and to ensure that no water would be condensed in the PSA unit, the gas stream is pressurised to $2 \mathrm{MPa}$ before entering the unit. As a result, the gas is not saturated with water when it enters the PSA unit. In the PSA unit, the gas is separated into two streams, one with high purity hydrogen and one with PSA offgas. The PSA unit is simulated as a separator where the hydrogen stream is of high purity (100\%). A combined gas-steam turbine unit was designed to utilise the off gas and generate electricity according to specifications found in the literature [37]. Finally, produced hydrogen needs to be compressed at high pressures equal to approximately $7 \mathrm{MPa}$. For this purpose a multi stage compressor (total 5 stages) with intermediate coolers was used. The net productivity of $\mathrm{H}_{2}$ is $6.8 \mathrm{th}^{-1}$.

\subsection{SNG production}

Gasified syngas after being quenched, purified and pressurized up to $3 \mathrm{MPa}$ is sent to the methanation area where the following catalytic reactions take place:

$$
\begin{aligned}
& \mathrm{CO}+3 \mathrm{H}_{2} \leftrightarrow \mathrm{CH}_{4}+\mathrm{H}_{2} \mathrm{O} \\
& \mathrm{CO}_{2}+4 \mathrm{H}_{2} \leftrightarrow \mathrm{CH}_{4}+2 \mathrm{H}_{2} \mathrm{O} \\
& \mathrm{CO}+\mathrm{H}_{2} \mathrm{O} \leftrightarrow \mathrm{H}_{2}+\mathrm{CO}_{2}
\end{aligned}
$$

Both of the methanation reactions ( 3 and 4) are highly exothermic $-206 \mathrm{~kJ} \mathrm{~mol}^{-1}$ and $-165 \mathrm{~kJ} \mathrm{~mol}^{-1}$, respectively - and therefore are favoured by low temperatures. Additionally high pressures will enhance the methane yield. Methane production from carbon dioxide is trigged by the water gas shift reaction [38]. Apart from the aforementioned reactions carbon might also be formed according to the following reactions:

$$
2 \mathrm{CO} \leftrightarrow \mathrm{CO}_{2}+\mathrm{C}(\mathrm{s})
$$


$\mathrm{CO}+\mathrm{H}_{2} \leftrightarrow \mathrm{C}(\mathrm{s})+\mathrm{H}_{2} \mathrm{O}$

In order to tackle this obstacle extra steam ( $671 \mathrm{~K}, 30$ bars) is supplied to the first reactor so as to promote the water gas shift reaction (5). In the present study the ICl methanation process approach [39] was adopted where the above reactions take place in three reactors in series coupled with intercoolers so as to achieve high methane yield and keep temperature at low levels. Gases enter the particular reactors at temperatures equal to $773 \mathrm{~K}, 673 \mathrm{~K}$ and $573 \mathrm{~K}$ [39]. All the reactors utilize nickel based catalysts. The operating conditions of the reactors prevent the catalyst deactivation. Similar to hydrogen production, three equilibrium reactors simulate the methanation unit. Afterwards the produced gas mixture is further cooled down so as to separate the condensed water, compressed up to $4 \mathrm{MPa}$ and sent to a MEA scrubbing unit as beforehand defined where $\mathrm{CO}_{2}$ is removed. SNG is produced at a rate of $14.2 \mathrm{t} \mathrm{h}^{-1}$. Heat released from the methanation section is exploited in a common Rankine cycle where high value steam ( $820 \mathrm{~K}, 80 \mathrm{bar})$ is generated to initiate a series of turbines. The final step is to increase the pressure of SNG to $5.5 \mathrm{MPa}$ (3 stage compressor) and feed it to the existing natural gas pipeline system. Simulation results are illustrated in Table 2.

(Table 2 here)

(Fig 1 here)

\section{Process evaluation}

\subsection{Exergy analysis}

The purpose of exergy analysis is to determine exergy losses (true thermodynamic losses) in processes and systems. Exergy analysis is more useful than energy analysis in measuring the efficiency of process since it identifies the causes, locations and magnitude of the system inefficiencies and includes irreversibility in the thermodynamic analysis. Exergy can be defined as the maximum useful work that can be obtained from a system at a given state in a given environment [40]. The calculation of exergy efficiency, $\psi$, is the most reliable way to evaluate the performance of one process and it was calculated by utilizing Eq. (8) [41]. The exergy efficiency, the most robust method of quantifying the efficiency of a process, compares the exergy content of the desired fuel to the exergy contained in the original feedstock in addition to all the chemical and net thermal exergy inputs required throughout the conversion process.

$\psi=\frac{\dot{m}_{\text {fuel }} E_{F u e l s}+E_{\text {out }}^{Q}+W_{\text {out }}}{\dot{m}_{\text {bagasse }} E_{\text {bagasse }}+E_{\text {in }}^{Q}+W_{\text {in }}}$

Where $\dot{m}_{f u e l}$ and $\dot{m}_{\text {bagasse }}$ are the mass flow rates of the produced fuels and bagasse, respectively and subscripts in and out stand for produced exergy flows and external exergy flows respectively. The exergy content of bagasse was calculated in a previous study and is equal to $280 \mathrm{MW}$ [42]. Work is considered as pure exergy while the exergy content of a heat stream, $E^{Q}$, is equal to [41]:

$E^{Q}=Q *\left(1-\frac{T_{0}}{T}\right)$

Where $T$ is the temperature at which $Q$ is available and $T_{0}$ the reference temperature ( $298 \mathrm{~K}$ throughout this study). The total exergy of a material stream has been calculated as the sum of the physical, $\varepsilon_{\mathrm{ph}}$, and chemical exergy, $\varepsilon_{\mathrm{ch}}$, multiplied by the mass flow rate [43]:

$$
\begin{aligned}
& \mathrm{E}=\mathrm{m}\left(\varepsilon_{p h}+\varepsilon_{c h}\right) \\
& \varepsilon_{\mathrm{ph}}=\mathrm{h}-\mathrm{h}_{0}-\mathrm{T}_{0} *\left(\mathrm{~s}-\mathrm{s}_{0}\right) \\
& \varepsilon_{\mathrm{ch}}=\sum_{i} x_{i} \varepsilon_{0, i}+\mathrm{R} T_{0} \sum_{i} x_{i} \ln x_{i}
\end{aligned}
$$


Where $h$ and $s$ are the mass enthalpy and entropy respectively at specific temperature $T, x_{i}$ the mass fraction of each component and $\varepsilon_{0 i}$ the standard chemical exergy of each substance All the necessary thermodynamic data was extracted from the simulations. Given the process technology modelled and integrated, and the assumptions made as described in the previous section, the SNG production achieves higher exergy efficiency than $\mathrm{H}_{2}$, i.e. $59.7 \%$ and $50.2 \%$ respectively. This difference can be explained by the relatively low $\mathrm{H}_{2}$ yields and the lower amount of electricity imports associated with the SNG process. As depicted in Fig. 2, for both processes the chief contributor to the exergy losses is the gasifier followed by the respective gas synthesis section. The total exergy losses were $170 \mathrm{MW}$ and $140 \mathrm{MW}$ for the $\mathrm{H}_{2}$ and the SNG routes respectively.

(Fig 2 here)

\subsection{Economic assessment}

The economic performance of each conversion route was assessed by calculating several financial indicators including net present value (NPV), internal rate of return (IRR), return on investment (ROI), payback period (PP) and the biofuel production cost. In this study a typical discounted cash flow analysis was performed. In particular, this evaluation relies on a cost benefit analysis that combines the capital investment, operating expenditures, total annualised cost budget, project incomes and money-making appraisal. The interest rate is equal to $7 \%$ per annum, the straight line depreciation method was selected (assets depreciated over 10 years), the annual operating hours were taken as 8000 , project lifetime was 20 years, and the tax rate was selected as $35 \%$. The selling prices of the products are $1.75 \$ \mathrm{~kg}^{-1}$ for $\mathrm{H}_{2}$ and $0.8 \$ \mathrm{~kg}^{-1}$ for SNG $[44,45]$ while operating costs $(\mathrm{OC})$ were adopted from relevant published data [45-48]. Operating costs comprise catalysts, utilities and labour expenditures. A focal step, when performing economic evaluation, is the calculation of the equipment cost (EC). For this purpose, the following equation, which is based on historic data, was utilised:

$C=C_{0}\left(\frac{S}{S_{0}}\right)^{f}$

Where $C$ is actual cost of the unit, $C_{0}$ is base cost of the unit, $S$ the actual size or capacity, $S_{0}$ the base size or capacity and $f$ the scale capacity factor. The values of the above variables have been adopted from the literature $[15,27,49,50,51]$ while the value of the $S$ variable from the simulations. The methodology proposed by Peters et al. [52] was adapted for the calculation of the total capital investment ( $\mathrm{TCl}$ ). According to this, the $\mathrm{TCl}$ derives from the summation of direct, indirect (both calculated as a percentage of the EC) and equipment costs. As depicted in Table 3, economic analysis favours the $\mathrm{H}_{2}$ process over the SNG, providing higher profits. This can be attributed to the high market value of hydrogen and the low capital costs which both compensate for its low yields.

(Table 3 here)

\subsection{Uncertainty analysis}

As discussed in section 3.2, the performance economic indicators (such as NPV) were estimated using several economic parameters presuming that these have a fixed value. Nevertheless, in reality the values of these parameters have a certain degree of uncertainty and are not known with absolute accuracy. To take into account these changes, uncertainty analysis was applied on the economic model based on Monte Carlo principles [53]. The goal of this analysis was to examine the behaviour NPV for random combinations of total capital investment, revenues, operating costs and interest rate. The values of these economic parameters varied from their calculated or base values within the bounds depicted in Table 4. The following histograms (Fig. 3) depict the results of the uncertainty analysis and additionally the mean value and standard deviation for each case were estimated. The risk analysis indicates that the $\mathrm{H}_{2}$ process seems to be more reliable through the changes of key 
economic factors since its mean value of NPV is more than the SNG case, i.e. M\$ 12 and M\$ 10 respectively as well as the standard deviation is lower, i.e. 95 and 117.

(Table 4 here)

(Fig 3 here)

\subsection{Effect of the plant size}

In addition, the effect of the plant size on biogases production cost was investigated. This was done by varying the input mass flow rate of bagasse. The results of this analysis are presented in Fig. 4. A second order decay trend can be observed for the production cost as the plant size increases. Beyond the baseline, the production cost slopes level out at a value of approximately $10.4 \$ \mathrm{GJ}^{-1}$ for the $\mathrm{H}_{2}$ and $11.1 \$ \mathrm{GJ}^{-1}$ for the SNG. The economies of scale favour the profitability of the processes, but one obstacle to this transition is the feedstock availability, since bagasse production is, of course, limited by the capacity of the plant from which it is a by-product. The equation utilised is the following [54]:

production cost $=$ base production cost $\times\left(\frac{\text { feedstock rate }}{\text { base feedstock rate }}\right)^{\left(1-\frac{1}{f}\right)}$

Where $f$ is the scale economic parameter and its suggested value for chemical processes is 0.85 [54].

(Fig 4 here)

\subsection{Environmental assessment}

Biofuels are recognised as a form of renewable energy and so far they are commonly treated as naturally carbon neutral sources, in the sense that carbon dioxide emitted from their combustion should not be reckoned since it is counterbalanced by $\mathrm{CO}_{2}$ uptake during photosynthesis process. However, this approach does not take into account emissions related with energy imported (e.g. pumping water, heat duties for the biomass conversion, fuel consumption for transport purposes) at any stage of the biofuel life cycle. In principal, the life cycle of a biofuel mainly consists of three steps, namely farming, biorefinery and end-use application. Carbon dioxide is emitted during all these steps. In this study, the emissions related to the conversion step of bagasse were calculated based on the simulations and it is sensible to consider that technologies with lower emissions will have a higher contribution to the development of a sustainable biofuel sector [55]. Furthermore, since this study deals with a single feedstock the emissions during farming can be considered equal for both the alternatives and thereby they can be neglected. Finally, clean combustion was considered as enduse utilisation of the biofuels and the emissions can be calculated from the respective reactions stoichiometry (zero for hydrogen). Additionally, in the calculations, the emissions related with producing steam (necessary for covering the heating duties) and electricity from conventional sources were also included. Typical values for $\mathrm{CO}_{2}$ emitted are $0.2 \mathrm{~kg} \mathrm{kWh}^{-1}$ for raising steam and 0.5 $\mathrm{kg} \mathrm{kWh}^{-1}$ for generating electricity [48]. As depicted in Fig. 5, the $\mathrm{H}_{2}$ production generates most of its emissions during the biorefinery step since the bagasse carbon content is converted to $\mathrm{CO}_{2}$ while in the case of SNG, most of $\mathrm{CO}_{2}$ is generated during its end use application. Furthermore, the higher demand of electricity and heat for the $\mathrm{H}_{2}$ production results in higher $\mathrm{CO}_{2}$ emissions compared to the SNG option, i.e. $790 \mathrm{kt} \mathrm{y}^{-1}$ and $740 \mathrm{kt} \mathrm{y}^{-1}$ respectively.

(Fig 5 here)

\subsection{Multicriteria decision analysis (MCDA)}

During the last few years, the necessity to determine the best option among the applicable alternatives and classify these alternatives according to their importance for a specific purpose, as well as the need to comparatively evaluate sophisticated technological and social-economic procedures, the use of quantitative multicriteria techniques has been extensively proposed and 
implemented. The key idea behind the quantitative assessment techniques is to efficiently integrate values of the criteria outlining a specific concept and their significance (known as weights) into a single magnitude. Depending on the project and selecting process, for some certain criteria the largest value is the desirable one, whereas for others the smallest value is the preferred. The scope of decision making process should be to: 1) To identify goals, 2) to identify alternatives for accomplishing these goals, 3 ) to identify the factors to be used to compare the alternatives, 4) to analyse of the alternatives and 5) to make choices. The appraisal of several engineering development projects involves consideration of different decision criteria. The multi-criteria framework allows such factors to be presented in a comprehensive and consistent format [56]. Simple Additive Weighting (SAW) is the oldest, most widely known and practically used method for multivariable analysis. The sum $S_{j}$ of the weighted normalized values of all the criteria is calculated for the $j$-th object as follows [57]:

$S_{j}=\sum_{i=1}^{m} w_{i} \overline{r_{i j}}$

Where $w_{i}$ is weight of the $\mathrm{i}$-th criterion $\left(\sum_{i=1}^{m} w_{i}=1\right) ; \overline{r_{l j}}$ is the normalized value of the $\mathrm{i}$-th criterion for the $j$-th object; $i=1, \ldots, n ; j=1, \ldots, m ; n$ is the number of criteria used, $m$ is the number of objects (alternatives) compared. The formulae that are used in order to maximize or minimize a criterion are the following [57]:

$\overline{r_{i j}}=\frac{\min _{j} r_{i j}}{r_{i j}}$

$\overline{r_{i j}}=\frac{r_{i j}}{\max _{j} r_{i j}}$

The criteria used in this study were exergy efficiency (rank 1), NPV (rank 2), $\mathrm{CO}_{2}$ emissions (rank 3 ) and mean NPV (rank 4). Exergy efficiency is the most reliable index to assess the feasibility of a process. The NPV was used as a profitability criterion, $\mathrm{CO}_{2}$ emissions to take into account the environmental impact of each alternative and the mean value of NPV the risk associated with each option. The normalised importance weight for each criterion can be calculated using Eq. (17) and Table 5 presents the resultant values of $w_{i}$ :

$w_{i}=\frac{n-r_{i}+1}{\sum_{i=1}^{n} n-r_{i}+1}$

(Table 5 here)

After defining the weight of each criterion it was possible to calculate the score, $S_{j}$, attributed to each conversion route. As depicted in Table 6, the SNG process attains higher overall score than the $\mathrm{H}_{2}$ route. It is pretty apparent that a vital factor, when MCDA is used, is the criteria ranking which can vary based on the objectives of the decision maker. As a result, if, for instance, the profitability is of the highest importance, then the $\mathrm{H}_{2}$ process outplays the SNG. Nevertheless, exergy efficiency should be considered the most crucial feasibility factor as it does not depend on external aspects, like market demand in the case of NPV.

(Table 6 here)

\section{Concluding remarks}

Two BtG processes were investigated in this study, namely hydrogen and SNG production. Comparative techno-economic and environmental analyses were performed in order to evaluate the feasibility of the processes. The methodology, utilised in the present study, combines the most important sustainability factors and builds a reliable decision-making tool that can be useful in assessing and comparing the sustainability of biomass conversion routes. Hence, the present study recommends only one process as the better option to utilise bagasse according only to the criteria that have been considered. In fact, a more thorough decision analysis depends on numerous aspects 
including criteria aside from those calculated in this research, such as the market demand, possible social concerns and the location of the plant.

Hydrogen production from biomass comes, by default, at low yields since its low content in the raw material ( $6 \%$ wt.) limits significantly the maximum potential yield. On the other hand, in methanation route most of the bagasse carbon goes to methane production and thereby higher product yields are achieved. As a result, the SNG route comes at higher exergetic efficiency.

Furthermore, $\mathrm{CO}_{2}$ emissions are higher for the $\mathrm{H}_{2}$ the option compared to the SNG procedure due to higher electricity and heat demands. Equally, the hydrogen market value is rather high mainly due to its demand in petrochemical plants and consequently its production provides higher profits. In addition, the distribution system of NG already exists while the distribution of hydrogen is still challenging. The study concludes with multicriteria analysis where the investigated options are evaluated on the same basis and the individual decision-making factors (exergy efficiency, $\mathrm{NPV}, \mathrm{CO}_{2}$ emissions and mean NPV) contribute to calculate an overall performance score. These scores are 95\% and $92 \%$ for SNG and $\mathrm{H}_{2}$ respectively. As a result, solely according to the criteria considered in this study, SNG provides a more sustainable way to exploit syngas derived from bagasse. 


\section{REFERENCES}

[1] B.S. Choudri, M. Baawain, Water Environment Research, 2015, 87(10), 1414-1444. DOI: $10.2175 / 106143015 \times 14338845155985$

[2] M.L. Savaliya, B.D. Dhorajiya, B.Z. Dholakiya, Research on Chemical Intermediates, 2015, 41(2), 475-509. DOI:10.1007/s11164-013-1231-z

[3] R.E.H. Sims, W. Mabee, J.N. Saddler, M. Taylor, Bioresource Technology, 2010, 101(6), 15701580. DOI:10.1016/j.biortech.2009.11.046

[4] J. Kopyscinski, T.J. Schildhauer, S.M.A. Biollaz, Fuel, 2010, 89(8), 1763-83. DOI:10.1016/j.fuel.2010.01.027

[5] C. Mao, Y. Feng, X. Wang, G. Ren, Renewable and Sustainable Energy Reviews, 2015, 45, 540555. DOI: 10.1016/j.rser.2015.02.032

[6] C. Tagliaferri, S. Evangelisti, R. Clift, P. Lettieri, C. Chapman, R. Taylor, Journal of Cleaner Production, 2016, 129, 144-158. DOI: 10.1016/j.jclepro.2016.04.092

[7] B. Steubing, R. Zah, C. Ludwig, Biomass and Bioenergy, 2011, 35(7), 2950-2960.

DOI:10.1016/j.biombioe.2011.03.036

[8] M. Juraščík, A. Sues, K.J. Ptasinski, Energy, 2010, 35(2), 880-888.

DOI:10.1016/j.energy.2009.07.031

[9] A. Duret, C. Friedli, F. Maréchal, Journal of Cleaner Production, 2005, 13(15), 1434-1446. DOI:10.1016/j.jclepro.2005.04.009

[10] C.R. Vitasari, M. Jurascik, K.J. Ptasinski, Energy, 2011, 36(6), 3825-3837. DOI:10.1016/j.energy.2010.09.026

[11] Z. Fang, R.L. Smith, X. Qi, Production of Hydrogen from Renewable Resources, Springer Netherlands, 2015.

[12] J. Moreno, J. Dufour, International Journal of Hydrogen Energy, 2013, 38(18), 7616-7622. DOI:10.1016/j.ijhydene.2012.11.076

[13] J. Dufour, D. P. Serrano, J. L. Gálvez, J. Moreno, C. García, International Journal of Hydrogen Energy, 2009, 34(3), 1370-1376. DOI:10.1016/j.ijhydene.2008.11.053

[14] S. Sarkar, A. Kumar, Energy, 2010, 35(2), 582-591. DOI:10.1016/j.energy.2009.10.029

[15] S. Sarkar, A. Kumar, Bioresource Technology, 2010, 101(19), 7350-7361. DOI:10.1016/j.biortech.2010.04.038

[16] A. Sordi, E.P. Silva, L.F. Milanez, D.D. Lobkov, S.N.M. Souza, Brazilian Journal of Chemical Engineering, 2009, 26(1), 159-169. DOI:10.1590/S0104-66322009000100015

[17] P. Spath, A. Aden, T. Eggeman, M. Ringer, B. Wallace, J., Jechura, 2005, Technical Report NREL/TP-510-37408 (National Renewable Energy Laboratory, Colorado, USA), Biomass to Hydrogen Production Detailed Design and Economics Utilizing the Battelle Columbus Laboratory IndirectlyHeated Gasifier

[18] Y. Guo, S. Z. Wang, D. H. Xu, Y. M. Gong, H. H. Ma, X. Y. Tang, Renewable and Sustainable Energy Reviews, 2010 14(1), 334-343. DOI: 10.1016/j.rser.2009.08.012.

[19] S. N. Reddy, S. Nanda, A. K. Dalai, J. A. Kozinski, International Journal of Hydrogen Energy, 2014, , 39(13), 6912-6926. DOI:10.1016/j.ijhydene.2014.02.125. 
[20] D. Liuzzi, F. J. Pérez-Alonso, J. L. G. Fierro, S. Rojas, F. L. van Wijk, I. Roghair, D. A. P. Tanaka, Catalysis Today, 2016, 268, 37-45. DOI:10.1016/j.cattod.2015.11.014.

[21] T. Pang, J. Y. S. Lin, Journal of Shanghai Jiaotong University (Science), 2015, 20(2), 228-233. DOI:10.1007/s12204-015-1612-0

[22] Y. Gao, J. Xu, Y. Zhang, Q. Yu, Z. Yuan, Y. Liu, Bioresource Technology, 2013, 144, 396-400. DOI:10.1016/j.biortech.2013.06.036

[23] M. Gassner, F. Maréchal, Biomass and Bioenergy, 2009, 33(11), 1587-1604. DOI:10.1016/j.biombioe.2009.08.004

[24] AspenTech, Aspen Plus, Getting Started Modeling Processes with Solids, 2013.

[25] S. Luo, C. Liu, B. Xiao, L. Xiao, Renewable Energy, 2011, 36, 578-582. DOI: 10.1016/j.renene.2010.08.003

[26] M. Sudiro, A. Bertucco, Energy, 2009, 34(12), 2206-2214. DOI:10.1016/j.energy.2008.12.009

[27] F. Trippe, M. Fröhling, F. Schultmann, R. Stahl, E. Henrich, Fuel Processing Technology, 2011, 92(11), 2169-2184. DOI:10.1016/j.fuproc.2011.06.026.

[28] D. Swierczynski, C. Courson, A. Kiennemann, Chemical Engineering and Processing: Process Intensification, 2008, 47(3), 508-513. DOI:10.1016/j.cep.2007.01.012.

[29] R. Zhang, H. Wang, X. Hou, Chemosphere, 2014, 97, 40-46. DOI: 10.1016/j.chemosphere.2013.10.087.

[30] J. Herguido, J. Corella, J. Gonzalez-Saiz, Industrial \& Engineering Chemistry Research, 1992, 31(5), 1274-1282. DOI:10.1021/ie00005a006

[31] P. J. Woolcock, R. C. Brown, Biomass and Bioenergy, 2013, 52, 54-84. DOI:10.1016/j.biombioe.2013.02.036.

[32] C.C. Sreejith, C. Muraleedharan, P. Arun, International Journal of Green Energy, 2013, 10(6), 610-639. DOI:10.1080/15435075.2012.709203

[33] Z. Min, M. Asadullah, P. Yimsiri, S. Zhang, H. Wu, C.-Z. Li, Fuel, 2011, 90(5) 1847-1854. DOI:10.1016/j.fuel.2010.12.039

[34] K. Hou, R. Hughes, Chemical Engineering Journal, 2001, 82(1-3), 311-328. DOI:10.1016/S1385-8947(00)00367-3

[35] P.J.G. Huttenhuis, N.J. Agrawal, J.A. Hogendoorn, G.F. Versteeg, Journal of Petroleum Science and Engineering, 2007, 55(1-2), 122-134. DOI:10.1016/j.petrol.2006.04.018

[36] S. Sircar, T.C. Golden, Sep Sci Technol., 2000, 35(5), 667-687. DOI: 10.1081/ SS-100100183

[37] M.J. De Kam, R. Vance Morey, D.G. Tiffany, Energy Conversion and Management, 2009, 50(7), 1682-1690. DOI:10.1016/j.enconman.2009.03.031

[38] F. Ullmann, W. Gerhartz, Y. S. Yamamoto, F. T. Campbell, R. Pfefferkorn, J. F. Rounsaville, ULMANN's Encyclopedia of Industrial Chemistry, 5th ed., VHC, Weinheim 1989

[39] B. B. Pearce, M. V. Twigg, C. Woodward, in Catalyst Handbook (Ed. M. V. Twigg), Wolfe Publishing Ltd., London 1989, Ch. 7

[40] M. Juraščík, A. Sues, K. J. Ptasinski, Energy and Environmental Science, 2009, 2(7), 791-801. DOI: $10.1039 / B 820824 G$

[41] B. Linnhoff, H. Dunford, R. Smith, Chemical Engineering Science, 1983, 38(8), 1175-1188. DOI:10.1016/0009-2509(83)80039-6 
[42] S. Michailos, D. Parker, C. Webb, Biomass and Bioenergy, 2016. DOI: 10.1016/j.biombioe.2016.06.019

[43] S.R. Park, A.K. Pandey, V.V. Tyagi, S.K. Tyagi, Renewable and Sustainable Energy Reviews, 2014, 30, 105-123. DOI:10.1016/j.rser.2013.09.011

[44] K.J. Ptasinski, M.J. Prins, A. Pierik, Energy, 2007, 32(4), 568-574.

DOI:10.1016/j.energy.2006.06.024

[45] L. Tao, X. He, E. C. D. Tan, M. Zhang, and A. Aden, Biofuels, Bioproducts and Biorefining, 2014, 8(3) 342-361. DOI: 10.1002/bbb.1462

[46] P. L. Spath, D.C. Dayton, Technical Report NREL/TP-510-34929, 2003, Preliminary screening technical and economic assessment of synthesis gas to fuels and chemicals with emphasis on the potential for biomass-derived syngas

[47] A. C. Caputo, M. Palumbo, P. M. Pelagagge, and F. Scacchia, Biomass and Bioenergy, 2005, 28(1) 35-51. DOI:10.1016/j.biombioe.2004.04.009

[48] A. Vlysidis, M. Binns, C. Webb, C. Theodoropoulos, Energy, 2011, 36 (8), 4671-4683. DOI:10.1016/j.energy.2011.04.046

[49] B. Bao, M. M. El-Halwagi, N. O. Elbashir, Fuel Processing Technology, 2010, 91(7), 703-713. DOI:10.1016/j.fuproc.2010.02.001

[50] J. Sadhukhan, K. S. Ng, E. M. Hernandez, Economic Analysis. Biorefineries and Chemical Processes, John Wiley \& Sons, Ltd, 2014.

[51] M. Aghabararnejad, G. S. Patience, J. Chaouki, Chemical Engineering \& Technology, 2015, 38, (5), 867-878.DOI: 10.1002/ceat.201400503

[52] M. Peters, K. Timmerhaus, R. West, Plant Design and Economics for Chemical Engineers. McGraw-Hill Education, 2003.

[53] G.M. Morgan, M. Henrion, Uncertainty: A Guide to Dealing with Uncertainty on Quantitative Risk and Policy Analysis. Cambridge University Press, Gambridge, UK, 1990.

[54] E. Martinez-Hernandez, M. H. Ibrahim, M. Leach, P. Sinclair, G. M. Campbell, J. Sadhukhan, Biomass and Bioenergy, 2013, 50, 52-64. DOI:10.1016/j.biombioe.2013.01.001

[55] M.G. Varanda, G. Pinto, F. Martins, Fuel Processing Technology, 2011, 92(5), 1087-1094. DOI:10.1016/j.fuproc.2011.01.003

[56] F.B. Ahmad, Z. Zhang, W.O.S. Doherty, I.M. O'Hara, Bioresource Technology, 2015, 190, 264273. DOI:10.1016/j.biortech.2015.04.083

[57] V. Podvezko, Inzinerine Ekonomika-Engineering Economics, 2011, 22(2), 134-146. DOI:10.5755/j01.ee.22.2.310 


\section{Tables and Headings}

Table 1 - Typical bagasse Proximate and Ultimate analysis [11]

\begin{tabular}{ll}
\hline Proximate analysis & \\
\hline Parameters & Mass fraction \%) \\
\hline Moisture & $50(\mathrm{wb})$ \\
Ash & $3.2(\mathrm{db})$ \\
Volatile matter (dry Basis) & $83.65(\mathrm{db})$ \\
Fixed Carbon (dry basis) & $13.15(\mathrm{db})$ \\
\hline Ultimate analysis & \\
\hline Element & Dry Weight (\%) \\
\hline C & 45.38 \\
H & 5.96 \\
O & 45.21 \\
$\mathrm{~N}$ & 0.15 \\
S & 0.1 \\
\hline
\end{tabular}

Table 2 - Simulation results

\begin{tabular}{lll}
\hline & SNG & $\mathrm{H}_{2}$ \\
\hline Heating duties (MW) & 110 & 160 \\
Cooling duties (MW) & 138 & 113 \\
Heat generated & 80 & 60 \\
Electricity generation (MW) & 15 & 12 \\
Electricity consumption (MW) & 18 & 23 \\
SNG productivity $\left(\mathrm{t} \mathrm{h}^{-1}\right.$ ) & 14.2 & - \\
SNG exergy content (MW) & 230 & - \\
$\mathrm{H}_{2}$ productivity $\left(\mathrm{t} \mathrm{h}^{-1}\right.$ ) & - & 6.8 \\
$\mathrm{H}_{2}$ exergy content $(\mathrm{MW})$ & - & 217 \\
\hline
\end{tabular}

Table 3. Economic results

\begin{tabular}{lcc}
\hline & $\mathrm{H}_{2}$ & SNG \\
\hline NPV (M\$) & 35 & 31 \\
IRR (\%) & 15.7 & 14.4 \\
ROI (\%) & 18.5 & 17.2 \\
PP (years) & 5.5 & 6.5 \\
TCI (M\$) & 320 & 340 \\
OC (M\$) & 50 & 44 \\
Production cost (\$ GJ & 12.1 & 12.9 \\
\hline
\end{tabular}

This article is protected by copyright. All rights reserved. 
Table 4. Limits used for key financial variables

\begin{tabular}{ll}
\hline Profitability factor & Variation (\%) \\
\hline $\mathrm{TCl}$ & -10 to 25 \\
$\mathrm{OC}$ & -15 to 25 \\
Revenues & -30 to 25 \\
Interest rate & -25 to 25 \\
\hline
\end{tabular}

Table 5 - Computation of normalised weights using ranking method

\begin{tabular}{lllll}
\hline Criteria & Rank position & Rank score $\mathbf{r}_{\mathrm{i}}$ & $\mathbf{n - r _ { \mathrm { i } } + \mathbf { 1 }}$ & $\mathbf{w}_{\mathbf{i}}$ \\
\hline Exergy efficiency & First & 1 & 4 & 0.4 \\
NPV & Second & 2 & 3 & 0.3 \\
CO $_{2}$ emissions & Third & 3 & 2 & 0.2 \\
Mean NPV & Fourth & 4 & 1 & 0.1 \\
\hline
\end{tabular}

Table 6 - Overall scores for the investigated options

\begin{tabular}{lcc}
\hline & SNG & $\mathrm{H}_{\mathbf{2}}$ \\
\hline Exergy efficiency & 1.00 & 0.84 \\
$\mathrm{NPV}$ & 0.89 & 1.00 \\
$\mathrm{CO}_{2}$ emissions & 1.00 & 0.94 \\
$\mathrm{Mean} N \mathrm{NV}$ & 0.83 & 1.00 \\
\hline $\mathrm{S}_{\mathrm{j}}(\%)$ & 95 & $\mathbf{9 2}$ \\
\hline
\end{tabular}




\section{Figures and captions}

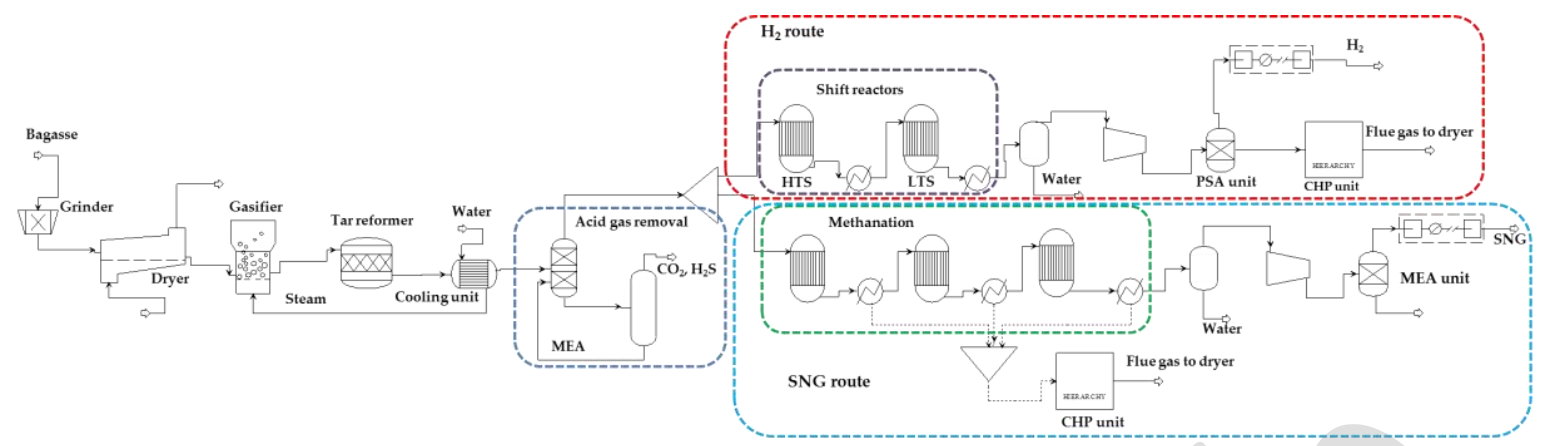

Figure 1. Simplified process schematic of $\mathrm{H}_{2}$ and SNG production from bagasse

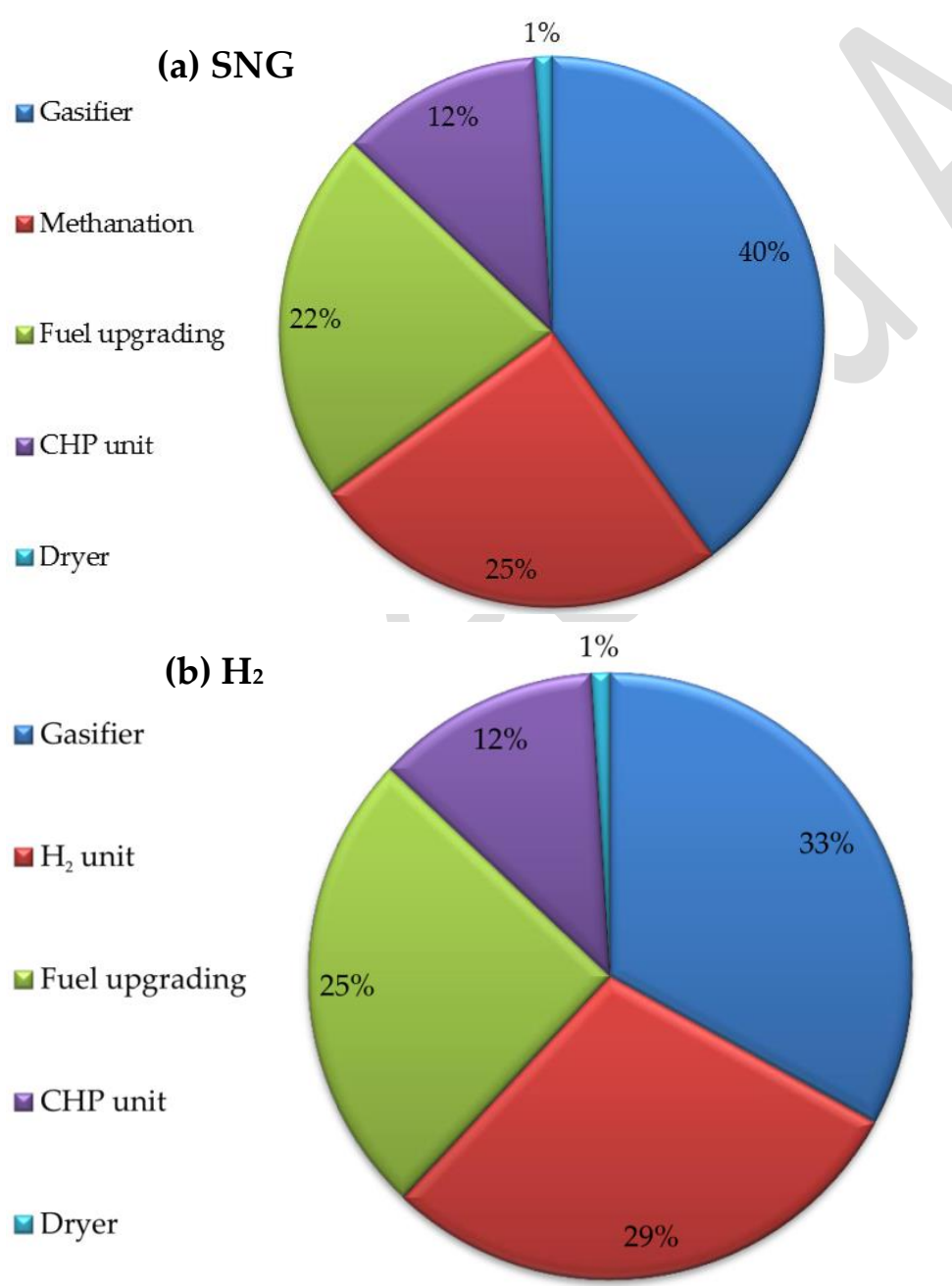

Figure 2. Exergy losses per section for each option ( $\left.a-\mathrm{SNG}, \mathrm{b}-\mathrm{H}_{2}\right)$ 

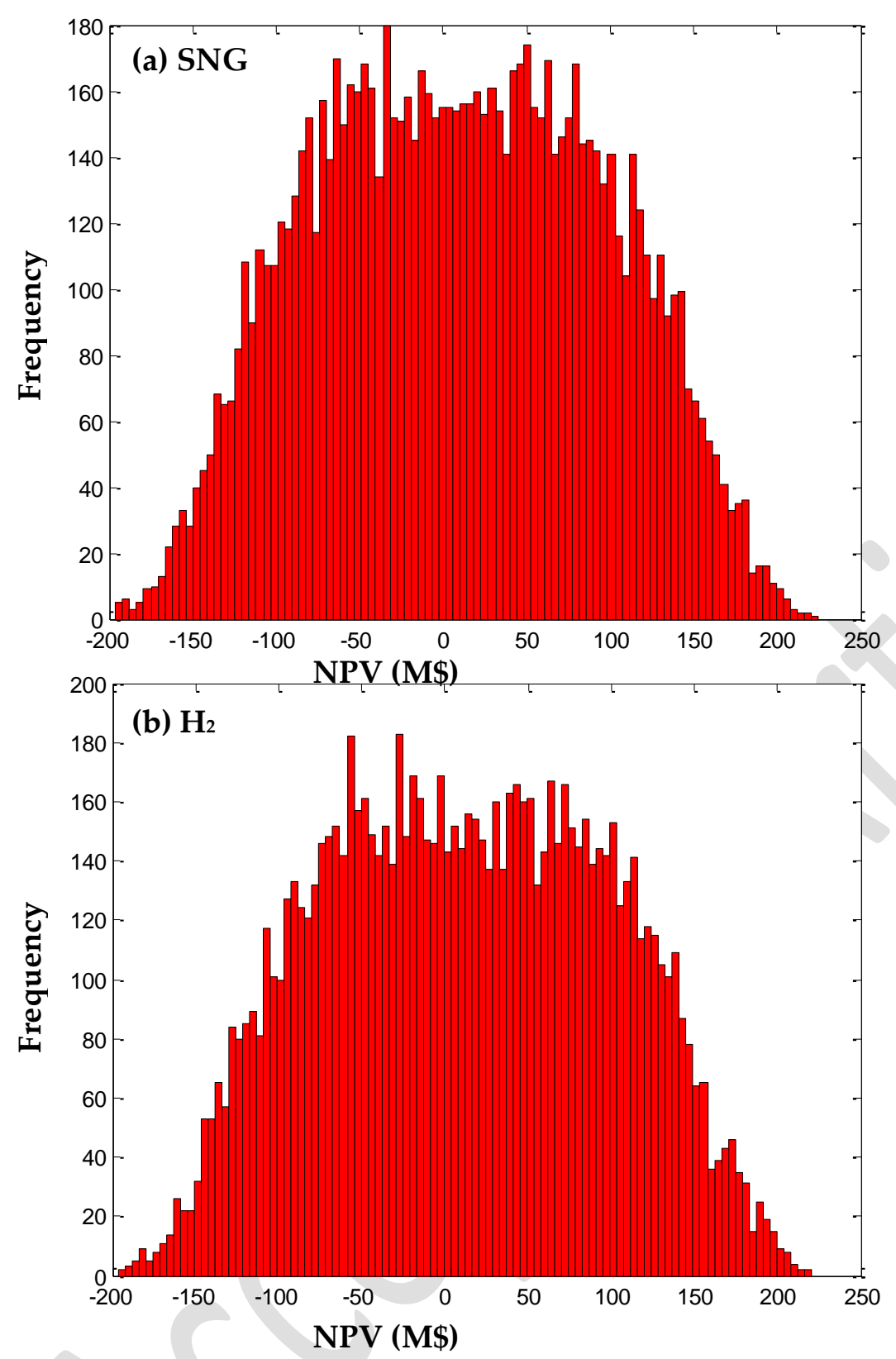

Figure 3. Risk analysis on NPV value for each alternative $\left(a-S N G, b-H_{2}\right)$ 


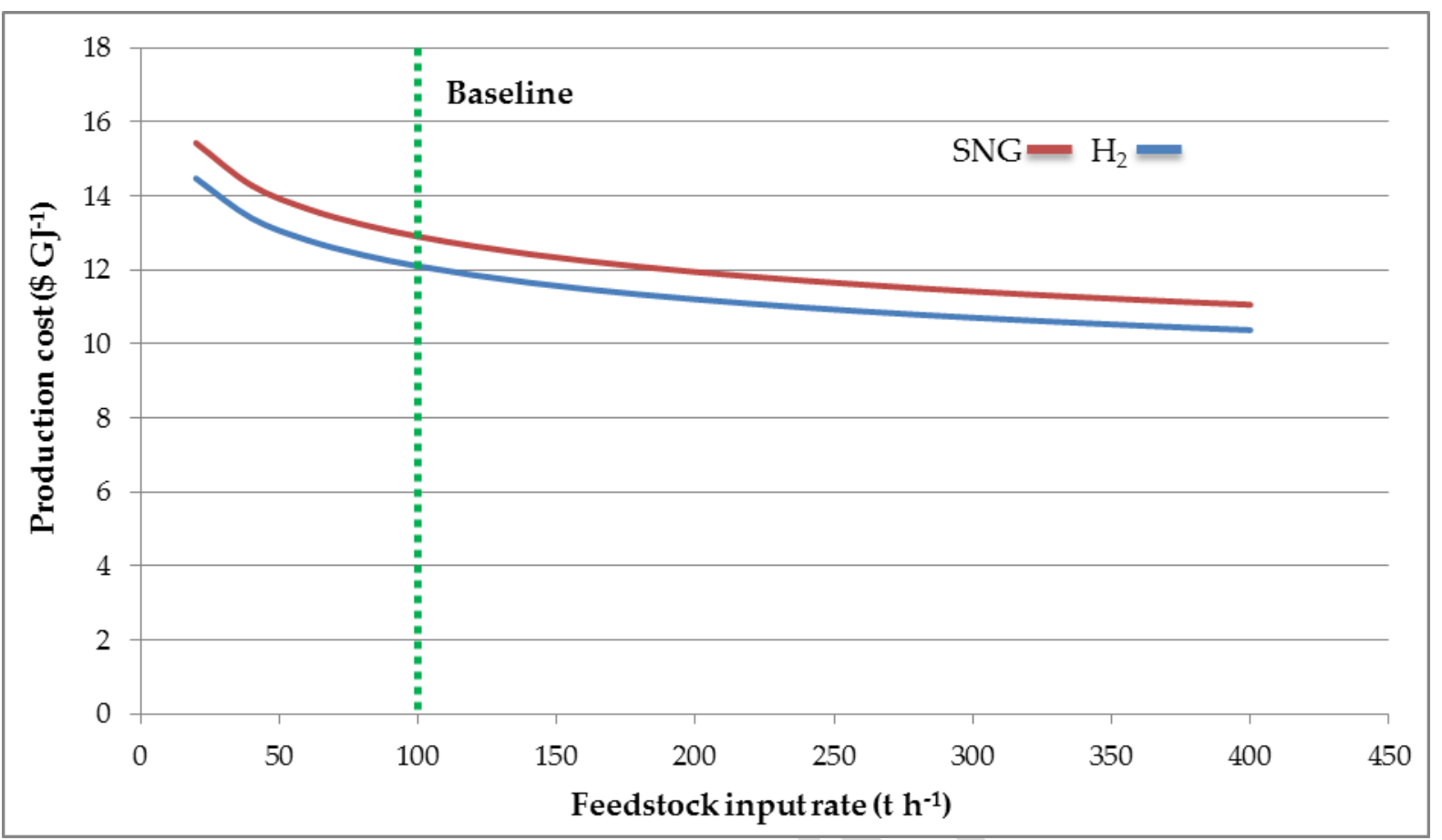

Figure 4. Effect of plant size on the production cost

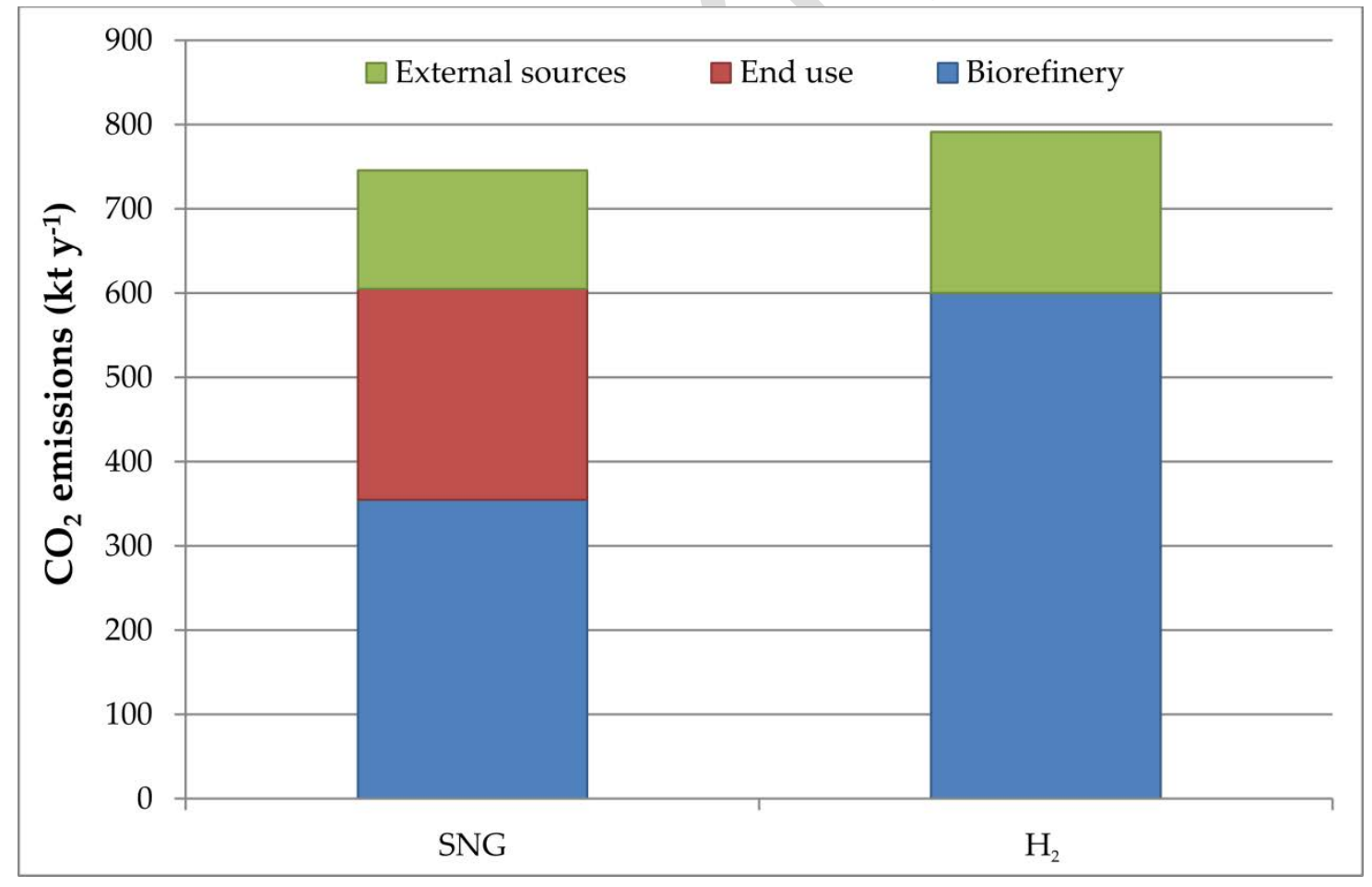

Figure 5. Calculated $\mathrm{CO}_{2}$ emissions for each conversion route 